\title{
THE BLACK AND WHITE OF GOFOOD CO-BRANDING
}

\author{
I Gusti Ngurah Bagus Dwira Palguna \& Agus Putu Abiyasa \\ Universitas Pendidikan Nasional, Denpasar, Indonesia
}

\begin{abstract}
This research aims to find out how the implementation of Gofood co-branding with its culinary partners, as well as to find out the pros and cons felt by partners since carrying out their cobranding with Gofood. This research is a qualitative research. The focus is on informants' personal, not specific companies or agencies, understanding. The data collection technique used is in-depth interviews with source triangulation as a data validity technique. The results obtained show that Gofood's co-branding with restaurant partners falls into the same type of co-branding but with different levels of co-branding and value creation. The pros felt by the partners lies in increasing sales, brand awareness and coverage of the sales areas while the thing that is a contra is pricing.
\end{abstract}

Keywords: co-branding, third-party online food delivery, business owner experience, Gofood

\section{INTRODUCTION}

The Internet of Things era in Indonesia is marked by the extensive benefits of internet connectivity which has been connected continuously in community activities. One of them is marked by the development of internet penetration in people's lives from year to year (Asosiasi Penyelenggara Jasa Internet Indonesia, 2018). Internet penetration which has increased significantly from 2016 to 2018 has also brought opportunities for innovative industrial businesses, where Gojek is one of them.

Gojek has now been transformed into a super application and as a major player in technology industry in Indonesia that has shown how technological innovation could expand income opportunities for all society levels. The existence of Gojek has been welcomed positively by the community and evidenced by the download of the Gojek application as much as 142 million times (Hastuti, 2019).

"Corresponding Author.

e-mail: eb.dwira@gmail.com

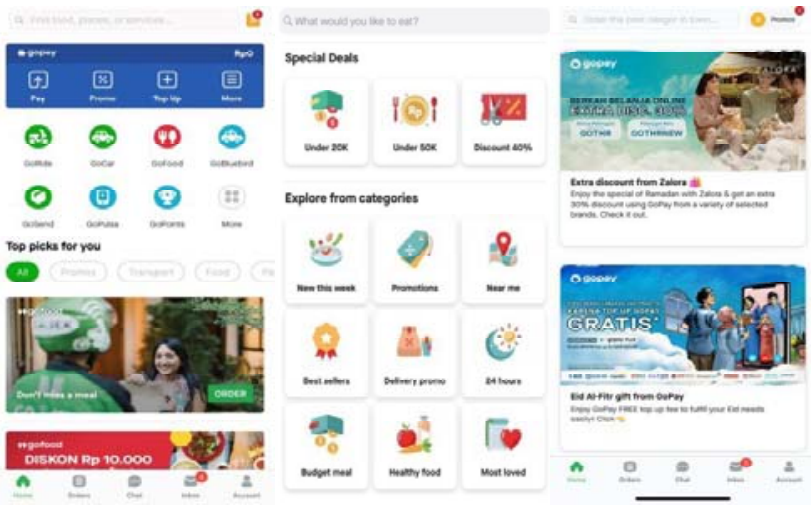

Figure 1 Gojek User Interface and Gofood Service Source: Walandouw, Primaldhi, Wisana, \& Nugroho (2018)

Gojek already had a range of services to meet the on demand needs which is incorporated in some groups, and the research results from the University of Indonesia's FEB Demographic Institute (LD FEB UI) in 2018 stated that the service that most contributed to national economy, specifically Bali economy was Gofood which has been known as an online food delivery service. Culinary business practi- 
I Gusti Ngurah Bagus Dwira Palguna \& Agus Putu Abiyasa / The Black and White of Gofood Co-Branding / JEE, Vol. 9, No. 2, September 2020, pp 57-68

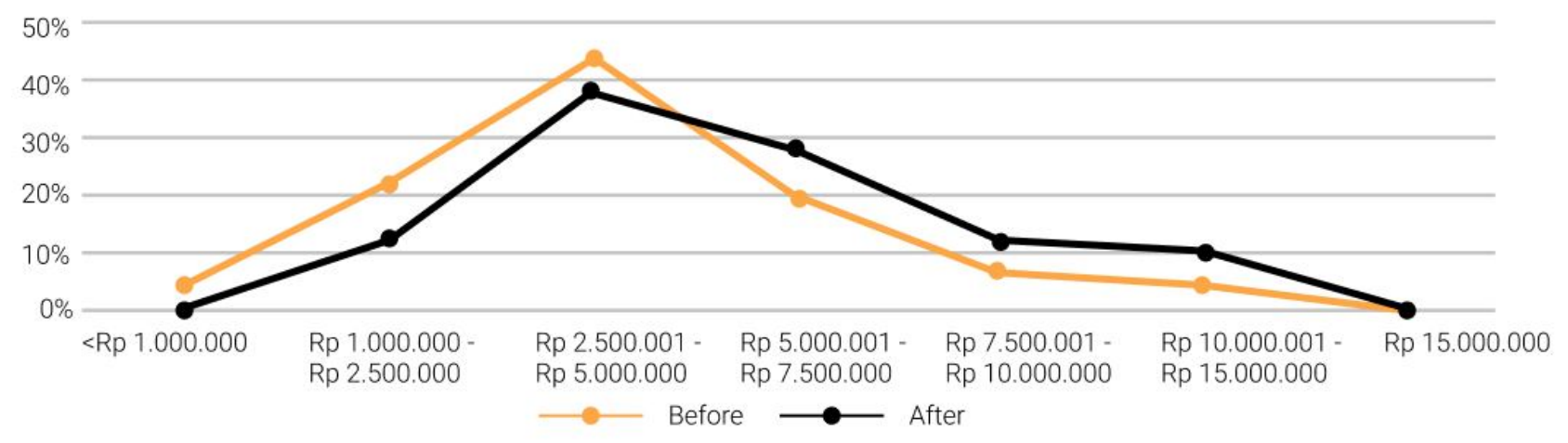

Figure 2 Weekly SMMEs Turnover from Non-partners to Gofood Partners

Source: (Walandouw et al., 2018)

tioners have experienced many benefits since their outlets have been registered on the Gofood application.

Figure 2 shows the comparison of culinary businesses percentage which experienced increased turnover before and after establishing partnership with Gojek. The picture shows partners have increased turnover in the range of 7.5 million to 15 million Indonesian Rupiah (Walandouw, Primaldhi, Wisana, \& Nugroho, 2018).

Figure 3 shows that most of Gojek culinary partners choose to allocate their increased turnover to be reinvested in their businesses. The rest chose to use the increased turnover for their employees, recruiting more employees, purchasing goods to support the businesses, and increasing their staff salaries (Walandouw et al., 2018).

Figure 4 shows an acknowledgement from a culinary partner of changes that have occurred in his business after establishing a partnership with Gofood, where popularity is an aspect that has been consistently changing (Walandouw et al., 2018). On the other hand, there are more people admit that only a few changes occur in terms of business coverage, customer satisfaction, customer improvement, and increased turnover. However, research re-

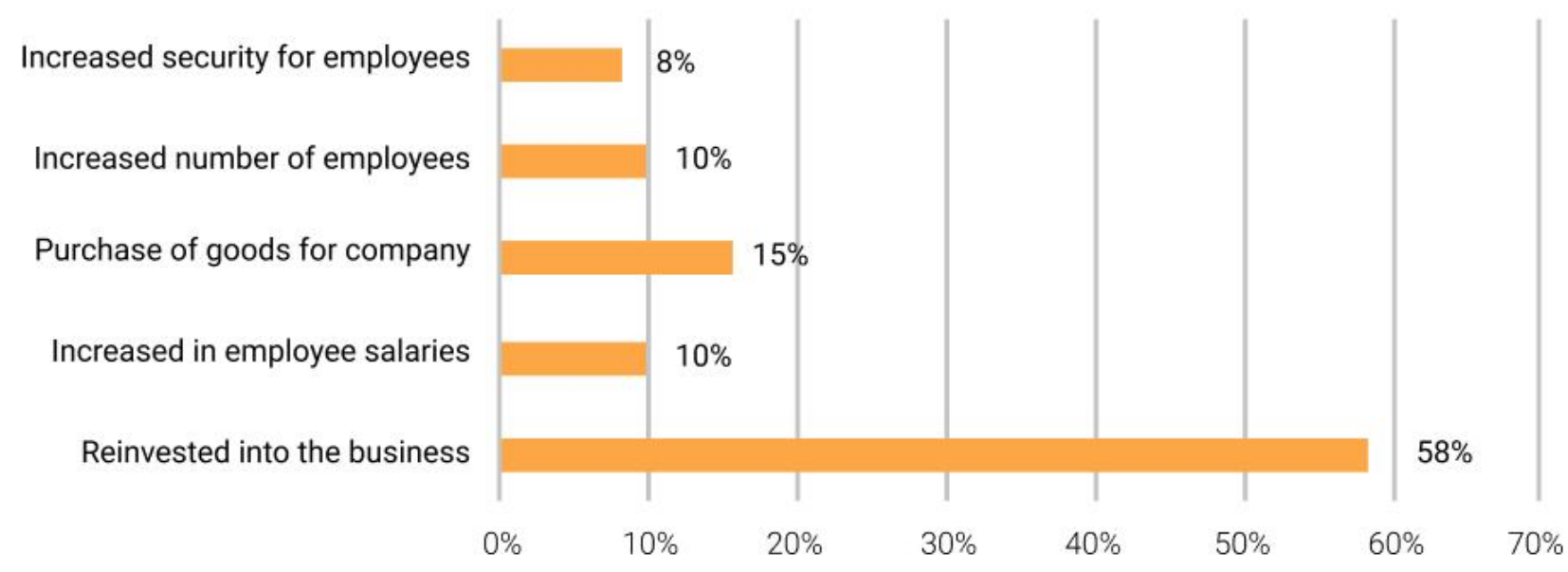

Figure 3 Increased Turnover Allocation Source: (Walandouw et al., 2018) 


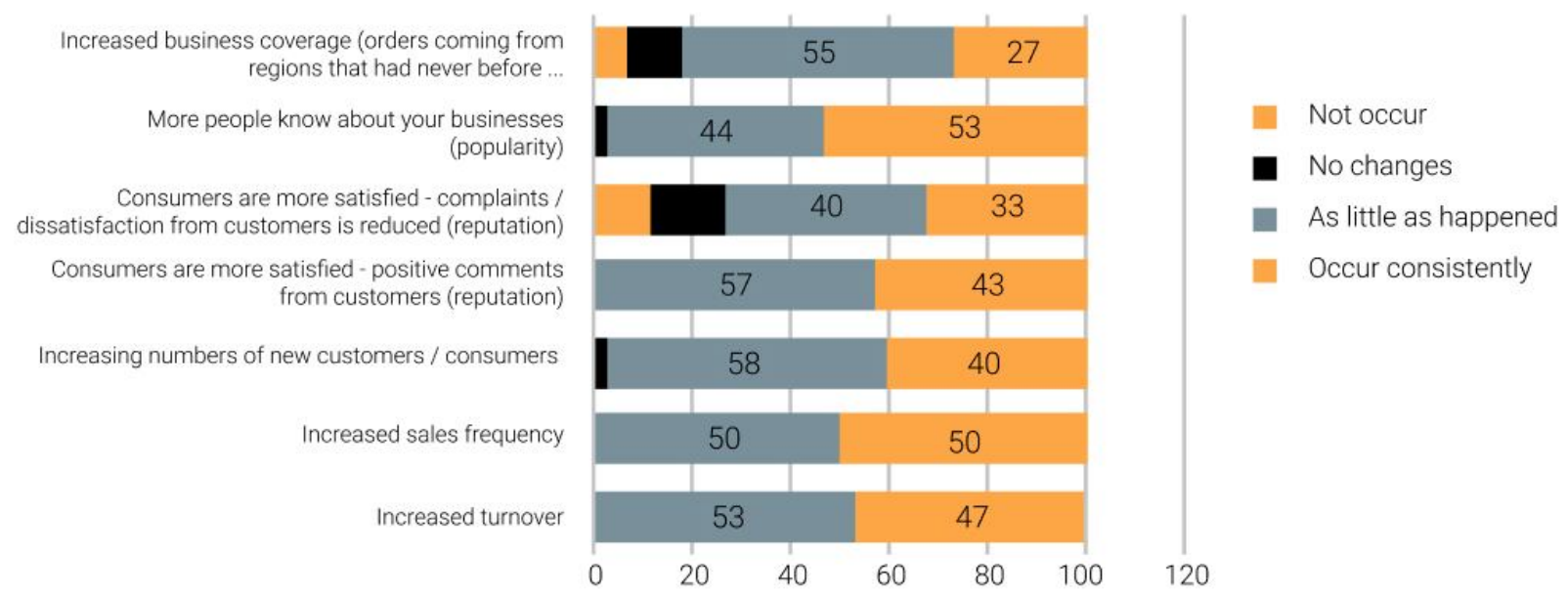

Figure 4 The Changes Occured after Joining Gofood in Denpasar (non-Partners) in 2018

Source: (Walandouw et al., 2018)

sults also show that there are SMMEs registered with Gofood, acknowledging that there have been no changes in their businesses after joining Gofood.

Huge internet penetration in this Internet of Things era has led to the increasing use of internet in culinary sector. Gofood flourished in creating a new phenomenon in society called by Nadiem Makariem, ex-CEO of Gojek, as the Shopping Addiction phenomenon (Palupi, 2019) as the Gojek's on-demand system allows consumers to use services immediately when they have needs, anywhere and anytime (van der Burg, Ahaus, Wortmann, \& Huitema, 2019). Consumers can shop for their needs without leaving home. From business players perspective, this phenomenon provides opportunities for culinary businesses to increase product transactions in Indonesia, as well as opening up opportunities to take electronic transaction advantages and the adoption of online food delivery services. Therefore, it is not surprising that more and more culinary entrepreneurs have been trying co-branding with Gofood.

This study aims to find out how the implementation of Gofood co-branding with its culi- nary partners and what the pros and cons are in running a co-branding activity based on culinary business players' experiences. There has been not much related researches and tend not to focus on Gofood. Sarinastiti \& Vardhani (2019 obtained the outcomes that Gofood cobranding with partners has been carried out jointly between Gofood and culinary tourism business players incorporated in Gofood Partner, but if not incorporated in Gofood Partner the joint co-branding has been carried out separately between Gofood and culinary tourism businesses. However, the study did not provide any outcomes regarding contra experience. The findings of See-Kwong, Soo-Ryue, Shiun-Yi, \& Lily (2017) in the study indicate factors that encourage the use of third-party online food delivery services, all problems encountered and suggestions from informants. But it did not focus on Gofood as an online food delivery service provider.

\section{METHOD}

This research was conducted in several culinary businesses that have been registered on 
I Gusti Ngurah Bagus Dwira Palguna \& Agus Putu Abiyasa / The Black and White of Gofood Co-Branding /

JEE, Vol. 9, No. 2, September 2020, pp 57-68

Gofood service located in Bali. The type of data used is qualitative data and informants are the subjects who understand the research object information as the actors, as well as other people who understand the research object. Data obtained from interviews with owners and/or managers of culinary businesses, with technique of checking data validity through source triangulation method. The focus is on informants' personal, not specific companies or agencies, understanding. Research subjects are the owner and managers of DS Fried Chicken, Escobar Coffee \& Co., Warung Bakso Ayu Minantri, and Kejink Pizza Canggu. In selecting the informants, the authors themselves choose the informants in accordance with this research objectives.

In selecting informants, the authors have the following criterions in accordance with $5 \mathrm{~W} 1 \mathrm{H}$ :

- What: Informants are players/owners or managers of culinary businesses that enter into partnership with Gofood.

- Who: The informant are the owners/managers of DS Chicken, Eskobar Kopi, Warung Bakso Ayu Minantri, and Kejink Pizza Canggu.

- Why: Informants are practitioners of culinary businesses and their businesses are registered on Gofood application.

- When: The research will be conducted within 2 months for interview in person. The timeframe is provided therefore informants who fall within the criterions can and are willing to be met and interviewed.

- Where: The interviews will be conducted in places agreed by the informants.

- How: The research will be conducted by interviewing the informants.

This study uses qualitative data analysis techniques with stages of data collection, data reduction, data presentation (data display), conclusions and data verification.

\section{RESULTS}

\section{Implementation of Gofood and Partners Co- branding}

In online food delivery service, restaurant partners display the menus in their application to attract more consumer interest, and consumers can order food online and send it to a predetermined location in a short time (Lan et al., 2016). This also applies to Gofood application as shown in Figure 5.

Gofood co-branding implementation has two cooperation system types; first, cooperation system where the business player is willing to establish cooperation with an official contract, it will be included in Gofood Partner community. Now Gofood Partner has been divided into 3 generations, they are Regular Gofood, GoBiz Partner, and Gofood Super Partner where the difference lies in the application features but all of them remain official Gofood Partners. Secondly, cooperation system where business player does not formally form a partnership through a contract then it does not enter Gofood Partner network but can still be displayed on the application (Sarinastiti \& Vardhani, 2019) or can be addressed as a NonGofood Partner.

Gofood allow consumers to compare offers and order meals from a group of restaurants, whether they are Gofood Partners or not. In addition, Gofood are compensated by the Gofood Partner restaurant with a $20 \%$ profit sharing of the order. Based on those statements, Gofood can be counted as the "New-Delivery" type, where Gofood are compensated by the restaurant with a fixed margin of the order and 

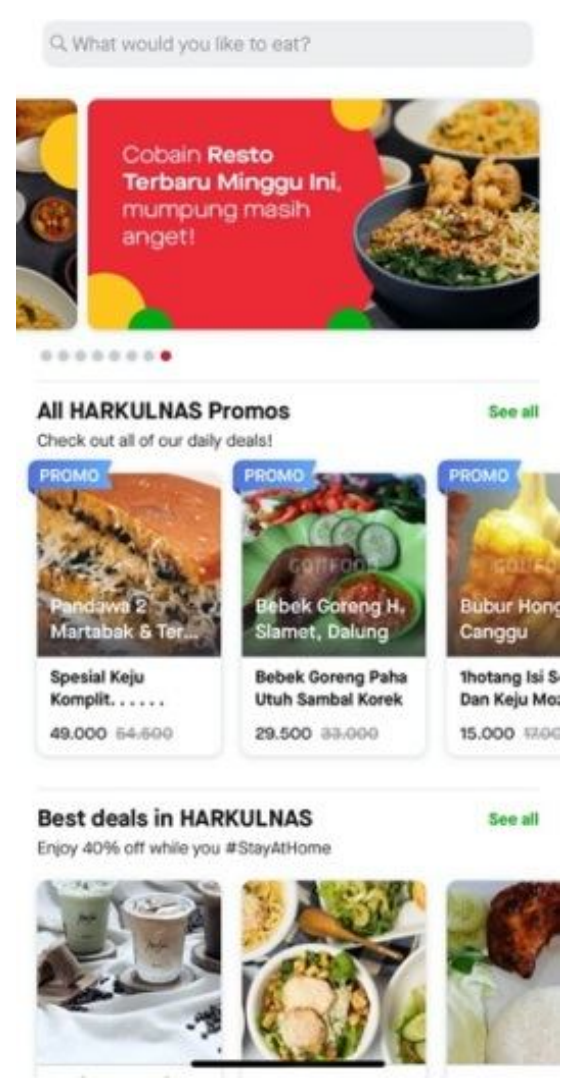

\section{.}

Figure 5 User Interface of Gofood
Source: Gojek Application iOS version

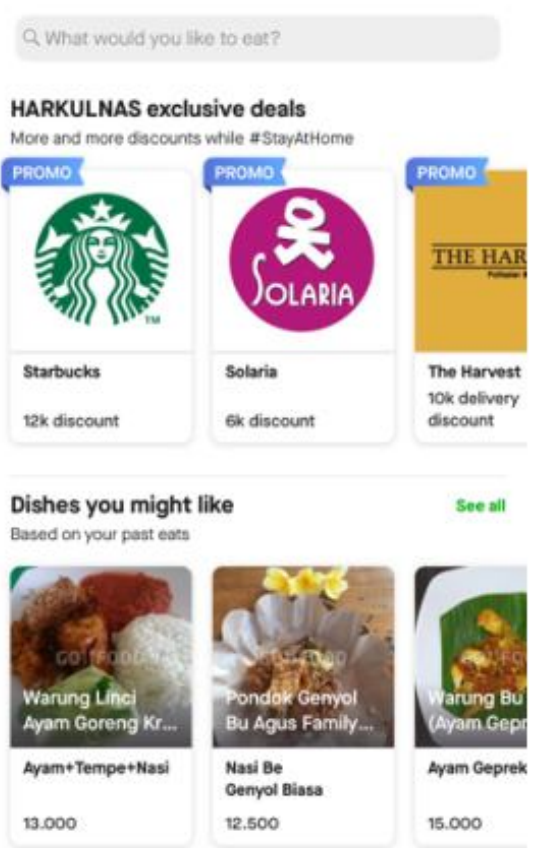

Explore from categories
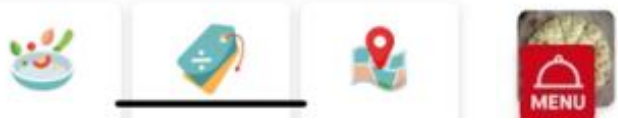

Available promos

O $4 \mathrm{k}$ delivery discount. No min, order

Paling laku

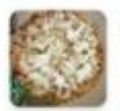

Bacon Pizza $20 \mathrm{~cm}$

Homemade tomato sauce, bacon, onion.

mozzarella cheese

23.000

Chicken Pizza $27 \mathrm{Cm}$

Homemade tomato sauce, chicken, onion. mozzarella cheose

45.000
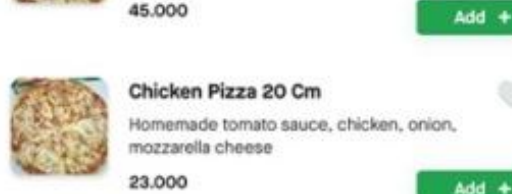

Chicken Pizza $20 \mathrm{~cm}$

Homemade tomato sauce, chicken, onion, mozzarella cheese

23.000

Makanan

\section{Margarita / Cheese Pizza 27cm}

Homemade tomato sauce, cheese mozzarella

35.000

Banana Pizza $27 \mathrm{~cm}$

Banana, sugar, mozzarella cheese

35.000

Table 1 Differences and Similarities between Gofood Partner and Non Gofood Partner

\begin{tabular}{|c|c|c|}
\hline Aspect & Gofood Partner & Non-Gofood Partner \\
\hline Partnership contract & $\begin{array}{l}\text { Official, must submit official data, such as personal } \\
\text { data, name, email, domicile, ID, tax payer number, } \\
\text { bank account details, and registered restaurant } \\
\text { outlet information. }\end{array}$ & $\begin{array}{l}\text { Unofficial. Not asked for personal data. } \\
\text { The menu list can be requested by the } \\
\text { driver or Gojek. }\end{array}$ \\
\hline Registrant & Owner/Manager & $\begin{array}{l}\text { Can be automatically registered without } \\
\text { the knowledge of owner/ manager. }\end{array}$ \\
\hline Access to Customers & $\begin{array}{l}\text { Can inform variety of superior products directly to } \\
\text { Gojek customers through Marketing Channel. }\end{array}$ & Cannot give information to customers. \\
\hline Access by customers & $\begin{array}{l}\text { Online outlets can be accessed by customers and } \\
\text { enter Gofood Partner network. }\end{array}$ & $\begin{array}{l}\text { Online outlets can be accessed by } \\
\text { customers but cannot be seen on } \\
\text { Gofood Partner network. }\end{array}$ \\
\hline $\begin{array}{l}\text { Management of } \\
\text { online restaurant }\end{array}$ & $\begin{array}{l}\text { Through GoBiz application, partners have access to } \\
\text { non-cash transactions, menu updates, product } \\
\text { availability and prices, setting opening hours for } \\
\text { restaurants, receiving orders faster, sorting menus } \\
\text { based on type, and adding branch outlets. GoBiz is } \\
\text { only available on Android Playstore. }\end{array}$ & $\begin{array}{l}\text { Cannot do management of online } \\
\text { restaurants. }\end{array}$ \\
\hline Promotions & $\begin{array}{l}\text { It is possible to promote best menus through } \\
\text { Gofood system. Can be involved in events held on } \\
\text { Gofood application. }\end{array}$ & $\begin{array}{l}\text { There is no product promoting feature } \\
\text { and cannot participate in the events. }\end{array}$ \\
\hline Compensation & $\begin{array}{l}\text { Profit sharing of } 20 \% \text { of sales via Gofood and small } \\
\text { delivery fee compensated by consumer }\end{array}$ & $\begin{array}{l}\text { There is no profit sharing but small } \\
\text { delivery fee compensated by consumer }\end{array}$ \\
\hline
\end{tabular}

Source: Data processed without year 
I Gusti Ngurah Bagus Dwira Palguna \& Agus Putu Abiyasa / The Black and White of Gofood Co-Branding /

JEE, Vol. 9, No. 2, September 2020, pp 57-68

delivery fee charges to consumers (Hirschberg et al., 2016).

In general, Gofood Partner can get more benefits from the use of Gofood, as shown in the Table 1, where the facilities that can be enjoyed are quite abundant and helpful in managing partners' culinary businesses. While NonGofood partners in general are only able to display their menus at online outlets.

Types and Levels of Gofood and Partners CoBranding

Other than the things that have been mentioned, Gofood gives differences which are official partners and which are not as shown in Figure 6 below.
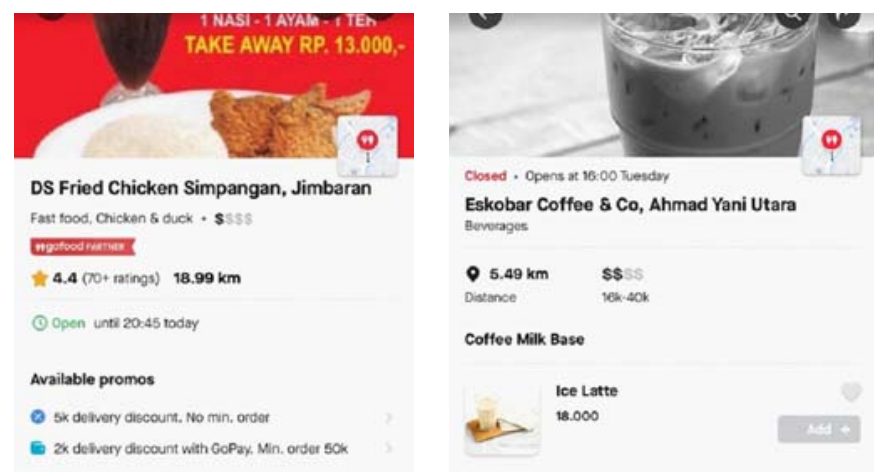

Figure 6 User Interface of Gofood Partner (Left) and Non Gofood Partner (Right) on Gofood Source: Gojek Application iOS version

DS Fried Chicken has been a Gofood Partner therefore it gets brand reinforcement with the official label Red Gofood Partner. In addition, available promos can be displayed to consumers. Unlike Eskobar Coffee \& Co which does not have an official Gofood Partner label as it belongs to Non Gofood Partner group, it can only display its outlets.

Based on co-branding type in Co-Branding Matrix, the two types of co-branding between Gofood and restaurants are in the form of joint ventures as they have to invest together (Chang, 2009). However, Gofood Partner is at the Department level where Gojek's Gofood Department deals with business-owned restaurants. Whereas Non-Gofood Partners do not reach the level of Gofood Department relationship with restaurants owned by business operators as they do not enter into official contracts. This is in line with what has been delivered by Sarinastiti \& Vardhani (2019) where the NonGofood Partners only reach each party but does not reach the combined business departments and companies. Nevertheless, the two types of co-brands enter the cooperation position where the two companies try to contribute each other excellence and help building good reputation. Gofood has great technological and network capabilities while restaurant partners have the ability to create food products, something that Gofood does not have.

In addition, Gofood also strengthens the position of its official partners which are members of Gofood Partner community, in this study, DS Fried Chicken and Kejink Pizza Canggu, by giving approval through Gofood Partner labels on restaurants as shown the following Figure 7.

\section{IY gofood PARTNER}

Figure 7 Official Gofood Partner Labels Source: Gojek Application

Therefore, based on the level of joint value creation (Blackett \& Boad, 1999), Gofood Partner is at the second level, Value Endorsement Branding which also includes the lower level, Knowledge Co-Branding, with the aim of increasing brand awareness where this is expressed in the following interview excerpt. "The consumers whose locations are far away can still buying food at my restaurant outlet. So my 
business scope can be wider and more recognizable" (Interview with DS Fried Chicken owner). This shows that Gofood Co-branding can increase consumer awareness of restaurants that appear on Gofood application. Supporting this, Gofood Partner has its own marketing network where Gofood categorizes partners and non-partners separately through the filter menu in its application so that it makes easier for consumers to find restaurants that have become partners. While Non-Gofood Partner type is at the first level, Knowledge CoBranding, which is indicated by the need for financial investment or profit sharing indicated by there is no need for financial investment and long-term contracts, but still aim to increase brand awareness (Blackett \& Boad, 1999; Fenger \& Carl, 2010). This is consistent to what has been stated by the following informants. "I don't need to pay anything to Gojek. My sales are based on offline menus and there is no requirement for profit sharing withholding as I'm not a Gofood Partner" (Interview with Eskobar Coffee \& Co owners and Bakso Ayu Minantri owners). Although there is no official contract, Non-Gofood Partner menus can still appear and be ordered but cannot be updated by the owners/managers due to feature restrictions.

\section{Overall Pro-Contra Experienced by Restaurant Owner}

Gofood generally gives satisfaction to its partners. Both types of partners felt positive impacts even though they felt different from each other due to differences in joint value creation and facilities provided by Gofood. There are pros and cons felt by informants as Gofood partners both official and unofficial as shown in Table 2.

Table 2 Pros \& Cons of Co-branding based on Informants' Experiences

\begin{tabular}{|c|c|}
\hline \multicolumn{2}{|c|}{ Gofood Partner } \\
\hline Pros & Cons \\
\hline $\begin{array}{l}\text { Comfort from the beginning of registration. } \\
\text { Businesses can be increasingly well known. }\end{array}$ & $\begin{array}{l}\text { There are deductions that are considered quite big } \\
\text { every time a transaction is made through Gofood. }\end{array}$ \\
\hline $\begin{array}{l}\text { Promotions in the form of discount coupons or other } \\
\text { promotions. }\end{array}$ & $\begin{array}{l}\text { Prices must be marked up in order to maintain profit } \\
\text { margin of each product. }\end{array}$ \\
\hline Helping to increase product sales. & $\begin{array}{l}\text { Prices tend to be higher than Non Gofood Partner } \\
\text { competitors. }\end{array}$ \\
\hline $\begin{array}{l}\text { scope of business, sales transactions, non-cash } \\
\text { transactions, account management, and avoid fake } \\
\text { transaction. }\end{array}$ & $\begin{array}{l}\text { There is a possibility of a fictitious orders if not using } \\
\text { Gobiz application. }\end{array}$ \\
\hline \multicolumn{2}{|c|}{ Non-Gofood Partner } \\
\hline Pros & Cons \\
\hline No need to register. & Menus and prices not updated. \\
\hline There is no charge for every transaction. & Not able to do promotion. \\
\hline Prices can be cheaper as there is no need to mark up & Not able to manage online outlets. \\
\hline prices. & Not an option for potential partners to choose from. \\
\hline Can have online outlets for free at no charge. & There is a possibility of getting complaints due to \\
\hline Helps increase sales. & differences prices on application and offline menu. \\
\hline
\end{tabular}

Source: Data processed without year. 
I Gusti Ngurah Bagus Dwira Palguna \& Agus Putu Abiyasa / The Black and White of Gofood Co-Branding / JEE, Vol. 9, No. 2, September 2020, pp 57-68

The most important benefits felt by partners who are either Gofood Partners or NonGofood Partners helping sales.

"I'm not registered as a Gofood Partner. Suddenly there are Gojek drivers who come even though not many. It turned out that my coffee was also ordered through Gofood. Gofood is really useful like when it was not so much offline sales but there are still those who buy online at least up to 10 glasses" (Interview with the owner of Eskobar Coffee \& Co).

Especially for Gofood Partners, Gofood can makes restaurants easy to be found and increases consumer awareness of their restaurant brands. In addition, they can find out the scope of sales territory and who their customers are through transactions displayed by GoBiz application. As stated in the following the quote:

"We can see who made orders. We could see their names, phone numbers, driver's name. So even after months or sometimes, I can still remember the names who made orders. I also know who just bought the products therefore I could see to what extent my product has been purchased" (Interview of the owner of Kejink Pizza Canggu).

The statement above also proves that there is a possibility that consumers get to know the registered restaurant brands even though the owner does not market them to these consumers. This finding is in accordance with SeeKwong et al. (2017) research that if restaurants use online food delivery service could reach wider customer areas and could increase sales as it is not limited by the number of seats and restaurant size. Especially for Gofood Partner informants, this is access for them for the first time utilizing non-cash financial transactions where this is considered to be very helpful in reducing fraud in cash transactions. As stated by the owner of the Kejink Pizza Canggu below.

\begin{abstract}
"Initially, before I used GoBiz, a number of times there have been unprincipled drivers who tell consumers that the prices of the products are different from the prices in the restaurant's menu. So those drivers ask for extra money from the consumers. Finally, I was suggested to try GoBiz. Now if someone pays by GoPay, I will directly enter my bank account, so there is no way a playful person will do it.
\end{abstract}

Satisfaction was also shown by Gofood Partner informants where they would highly recommend the use of Gofood in culinary businesses. Apart from pro experiences, there are also contra experiences where costs and pricing are becoming constraints. Gofood Partner considers the profit-sharing ratio is too high causing difficulty in determining prices. Furthermore, there are competitors who are registered as Non-Gofood Partners so there is no need to pay anything. As stated in the following interview excerpt.

"There are my competitors, other fried chicken sellers, they don't need to pay anything. So my price can't be the same as their prices at Gofood, while I have to pay 20\%. So here I am, it is hard to compete with competitors that are registered for free. The prices I set must be marked up to cover my costs" (Interview with the owner of DS Fried Chicken).

"I do not want to say that it is unfavourable, but there is just a sense of jealousy as the numbers are large and multiplied by thousands orders and restaurants so that Gofood side can get profit a lot. But in my opinion, it is in return for the technology they provide that helps us" (Interview with the owner of Kejink Pizza Canggu). 
Different from the case with Non-Gofood Partners who face constraints where the offline outlet prices do not match those listed on the application, therefore drivers who use cash transactions often do not have enough money to pay.

Regardless of the pros and cons stated, they assume Gofood is only a medium and does not immediately make the businesses famous but Gofood provides a way for those businesses to become better known. It goes back to the two most important things to increase brand awareness and sales; they are repetitive promotion and the ability to maintain the taste and quality of the product. This is accordance with (Alkhawaldeh, Al-Salaymeh, Alshare, \& Eneizan, 2017; Keller, 2003) that marketers can create brand awareness among customers through repetitive publicity and advertising. Gofood Partner informants provide a few suggestions for restaurant owners who are registered as Gofood Partner so that sales from Gofood are getting more optimal, i.e.:

1) Choose one or more products to promote as attractions. It means partners can place promos on 1 or 2 interesting products so they tempt consumers to enter the outlet and look at other menus.

2) The more often the promotion the better. It means, if partners often put up promotions then the possibility of being included in the filter and promo category on Gofood main page is getting higher. Things to consider is price reductions as of discounts and profitsharing deductions.

3) The photos and taste must match. It means, if partners decide to use good food photos, they must be balanced with good taste. This relates to the rating, if it is maintained at a high level, it will bring products and the restaurants into restaurant filters with high ratings therefore they tend to be more searched by consumers.

\section{DISCUSSION}

Gofood has changed the face of culinary businesses in Indonesia, especially for business players who become its partners and feel the benefits. Gofood Partners that have been developed started from Regular Gofood, GoBiz Partners and now developed into Gofood Super Partners, where informal Non-Gofood Partner partnerships still show its existence, but current partnership option for prospective partners is only Gofood Partner. Both types are co-branding with joint venture type with Cooperation level, but they have different levels of joint value creation where NonFood Partners are at the lowest level, that is Knowledge. While Gofood Partner is at the second level, Value Endorsement which also includes level one criterion. Partners generally feel the benefits where at least the transaction is maintained when the business has been low, as Gofood is there even though the number is not significant. In addition to Gofood's existence, Gofood Partners have access to digitalization through electronic transactions, consumer awareness of restaurant brands and the scope of sales areas are also increasing. The constraint for them is pricing. However, the informant strongly recommended the use of Gofood or other online food deliverers in running a culinary business. The results of this research can be a reference for culinary entrepreneurs to co-branding with Gofood as there are pros and cons that can be considered. The results can also be a consideration for the creative industry to provide value that Gofood lacks.

As this research focuses on culinary business owner's experience on Gofood co-brand- 
I Gusti Ngurah Bagus Dwira Palguna \& Agus Putu Abiyasa / The Black and White of Gofood Co-Branding /

JEE, Vol. 9, No. 2, September 2020, pp 57-68

ing implementation, the outcomes could not be generalized or used for other aspects of the food service industry. Furthermore, the use of semi-structured interview methods could imply inaccurate or biased information dependent on researchers' interpretation on the implicit meaning in the interviews. Therefore, source triangulation is used to reduce bias. It is also recommended for future research to conduct quantitative research for cross-validation checks along with qualitative research.

\section{REFERENCES}

Alkhawaldeh, A., Al-Salaymeh, M., Alshare, F., \& Eneizan, B. (2017). The Effect of Brand Awareness on Brand Loyalty: Mediating Role of Brand Commitment. European Journal of Business and Management, 9, 38-47. Retrieved from https://iiste.org/ Journals/index.php/EJBM/article/view/ 40349.

Asosiasi Penyelenggara Jasa Internet Indonesia. (2018). Penetrasi \& Profil Perilaku Pengguna Internet Indonesia. In APJII. Retrieved from www.apjii.or.id.

Blackett, T. \& Boad, R. (1999). Co-Branding/ : The Science of Alliance (1st ed.; T. Blackett \& B. Boad, Eds.). https://doi.org/10.1057/ 9780230599673.

Chang, W. L. (2009). Roadmap of Co-branding Positions and Strategies. Journal of American Academy of Business, Cambridge, 15(1), 77-84. Retrieved from https://www. semanticscholar.org/paper/Roadmap-ofCo-branding-Positions-and-StrategiesChang/41e47a168e233e5cc02b2c231f1 30821d8dcbe11.

Fenger, L. \& Carl, S. M. (2010). The Future of Co-branding, A Study of Cross-border
Brand Alliances (Copenhagen Business School). Retrieved from https://research. cbs.dk/en/studentProjects/75b52085-f6c6444c-ab30-8e0edc3f14b0.

Grieco, C., Iasevoli, G., \& Michelini, L. (2016). Marketing Alliances in Digital Firms: An Analysis of Benefits and Risks. https:// doi.org/10.7433/SRECP.FP.2016.06.

Hastuti, R. K. (2019). Gojek Telah Diunduh 142 Juta Kali. Retrieved from CNBC Indonesia website: https://www.cnbcindo nesia.com/tech/20190423171542-37-683 67/gojek-telah-diunduh-142-juta-kali.

Hirschberg, C., Rajko, A., Schumacher, T., \& Wrulich, M. (2016). The Changing Market for Food Delivery. Retrieved October 23, 2019, from McKinsey \& Company website: https://www.mckinsey.com/industries/technology-media-and-telecommunications/our-insights/the-changing-marketfor-food-delivery.

Keller, K. (2003). Brand Synthesis: The Multidimensionality of Brand Knowledge. Journal of Consumer Research, 29, 595-600. https://doi.org/10.1086/346254.

Kimes, S. E. (2011). The Current State of Online Food Ordering in the U.S . Restaurant Industry. Cornell Hospitality Report, 11(17), 6-18. Retrieved from https:/ /scholarship.sha.cornell.edu/chrpubs/73/.

Kotler, P. (2002). Marketing Management, Millenium Edition. Boston: Pearson Custom Publishing.

Lan, H., Ya, L. I., \& Shuhua, W. (2016). Improvement of Online Food Delivery Service Based on Consumers' Negative Comments. Canadian Social Science, 12(5), 84-88. https://doi.org/10.3968/8464.

Palupi, D. H. (2019). Membedah Booming GoFood dan GrabFood. Retrieved from SWA 
website: https://swa.co.id/swa/trends/marketing/membedah-booming-go-food-dangrabfood.

Sarinastiti, E. N. \& Vardhani, N. K. (2019). Co-branding Online Food Delivery: Perubahan Model Bisnis Wisata Kuliner Lokal Khas Yogyakarta. AdBispreneur, 3(3), 177. https://doi.org/10.24198/adbispreneur. v3i3.19157.

See-Kwong, G., Soo-Ryue, N., Shiun-Yi, W., \& Lily, C. (2017). Outsourcing To Online Food Delivery Services: Perspective of F\&B Business Owners. Journal of Internet Banking and Commerce, 22(2). Retrieved from http://www.icommercecentral.com/ open-access/outsourcing-to-online-food- delivery-services-perspective-of-fb-business-owners.pdf.

van der Burg, R. J., Ahaus, K., Wortmann, H., \& Huitema, G. B. (2019). Investigating the on-demand service characteristics: an empirical study. Journal of Service Management, 30(6), 739-765. https://doi.org/ 10.1108/JOSM-01-2019-0025.

Walandouw, P., Primaldhi, A., Wisana, I. D. G. K., \& Nugroho, A. H. (2018). Dampak GOJEK terhadap Perekonomian Denpasar pada Tahun 2018. Retrieved from https:/ /ldfebui.org/wp-content/uploads/2019/03/ LDUI-Dampak-GOJEK-pada-Perekonomian-Denpasar-2018.pdf. 
I Gusti Ngurah Bagus Dwira Palguna \& Agus Putu Abiyasa / The Black and White of Gofood Co-Branding / JEE, Vol. 9, No. 2, September 2020, pp 57-68 